\title{
PENGARUH KEPERCAYAAN DAN RESIKO TERHADAP SIKAP DAN PERILAKU DALAM MENGGUNAKAN APLIKASI MOBILE BERBASIS ANDROID
}

\author{
Agustinus Widyartono dan Maria Josephine Tyra \\ Fakultas Bisnis dan Akuntansi, Program Studi Manajemen, \\ Universitas Katolik Musi Charitas, Palembang \\ Email: widyartono@ukmc.ac.id; tyra@ukmc.ac.id
}

\begin{abstract}
The aim of this research is to test the impact risk and trust variable toward behavior with attitude of android mobile application user as mediating variable. Total sample that used in this research 100 respondent. Base on test, instrument that used in this research are valid and reliable. This research used Component Based SEM (Partial Least Square) as method analysis. The output from this research are: (1) Trust and attitude are mediating variable in relations between risk toward attitude and behavior; (2) Risk as attitude form factor and people attitude to use android mobile applications; (3) Risk had negative relations with trust and attitude, as high risk perceived will reduce trust toward applications and attitude; (4) Trust had positive relations toward attitude and attitude had positive relations toward behavior in used android mobile applications.
\end{abstract}

Key words: trust, risk, attitude, behavior, social.

Abstrak: Penelitian ini bertujuan untuk menguji pengaruh variabel resiko dan kepercayaan terhadap perilaku dengan mediasi variabel sikap dari pengguna aplikasi Mobile Berbasis Android. Sampel yang digunakan sebanyak 100 responden yang memiliki dan menggunakan aplikasi Mobile Berbasis Android. Berdasarkan pengujian, instrumen yang digunakan adalah valid dan reliabel. Metode analisis yang digunakan adalah Component Based SEM (Partial Least Square). Hasil penelitian membuktikan: 1. Variabel kepercayaan dan sikap adalah variabel mediasi hubungan antara resiko dengan sikap dan perilaku. 2. Resiko merupakan faktor yang membentuk sikap dan perilaku seseorang dalam menggunakan aplikasi mobile berbasis android. 3. Resiko berbanding terbalik dengan kepercayaan dan sikap, bahwa semakin tinggi resiko yang dirasakan akan menurunkan kepercayaan atas sebuah aplikasi dan sikap atas aplikasi tersebut. 4. Kepercayaan berbanding lurus dengan sikap dan sikap berbanding lurus dengan perilaku dalam menggunakan aplikasi berbasis android.

Kata kunci: kepercayaan, resiko, sikap, perilaku, sosial.

\section{PENDAHULUAN}

Perkembangan teknologi informasi membuat hidup menjadi lebih mudah. Kehadiran internet memberikan dampak yang luas bagi kehidupan. Dahulu pertukaran informasi melalui media internet hanya dilakukan untuk hal-hal yang berkaitan dengan pekerjaan atau pengelolaan bisnis. Saat ini media internet sudah digunakan sebagai sarana untuk mendekatkan diri dengan konsumen. Media internet dapat digunakan untuk mengetahui apa yang menjadi preferensi atau keinginan dari konsumen. Konsumen menjadi lebih cerdas dalam memilih dan lebih kritis atas layanan yang diterima. Kehadiran media 
internet membuat apa yang dahulu tidak tampak oleh perusahaan/pemasar dalam melayani konsumennya sekarang menjadi tampak.

Salah satu perangkat tekonologi informasi dan telekomunikasi yang berkembang dengan pesat adalah penggunaan smartphone. Telepon seluler yang dahulu hanya sebatas untuk melakukan pertukaran informasi melalui telepon dan SMS kini semakin berkembang. Smartphone tidak hanya memberikan fasilitas telepon dan SMS semata tetapi juga koneksi ke jalur internet. Maraknya penggunaan smartphone juga berdampak pada meningkatnya penggunaan internet.

Pertumbuhan penggunaan internet di Indonesia diprediksi akan terus meningkat. $E$ marketer memprediksi bahwa pada tahun 2017 jumlah netter (pengguna internet) di Indonesia akan mencapat 112 juta orang mengalahkan pengguna internet di Jepang. Menurut Monika Peart seorang analis senior E-marketer "ponsel dan koneksi broadband mobile terjangkau mendorong pertumbuhan akses internet di negara-negara yang tidak bisa mengandalkan fixed line, entah karena masalah infrastruktur atau biaya". Peart menyebutkan bahwa negara berkembang seperti Indonesia dan India masih memiliki ruang pertumbuhan jumlah pengguna internet yang besarnya bisa mencapai dua digit setiap tahun (Yusuf, 2014).

Kehadiran smartphone berbasis android memudahkan pengguna dalam mengakses informasi. Smartphone berbasis android menawarkan kemudahan dalam penggunaan, kemudahan dalam pemasangan aplikasi dan koneksi ke jaringan internet. Smartphone yang merupakan perangkat mobile sudah menggeser penggunaan laptop atau notebook sebagai peralatan yang biasa digunakan untuk mengakses jaringan internet. Ukuran yang proporsional dibandingkan dengan laptop atau notebook mengakibatkan smartphone menjadi perangkat pilihan untuk berselancar di internet.

Memang diakui bahwa popularitas, kemudahan dalam penggunaan menjadi patokan apakah sebuah perangkat teknologi informasi akan diadopsi atau tidak. Android dengan kemudahan dalam pengoperasiannya serta ketersediaan perangkat lunak pendukung menjadikannya semakin populer. Saat produk selular yang lain masih menggunakan sistem berbayar untuk semua aplikasi pendukungnya tidak demikian dengan android. Produk selular atau smartphone berbasis android memudahkan para penggunanya dalam memasang aplikasi pendukung dengan meyediakan pilihan apakah akan menggunakan aplikasi pendukung yang harus dibeli atau gratis. Aplikasi-aplikasi pendukung yang tersedia mulai dari aplikasi yang bersifat hiburan, multimedia bahkan sampai pengolahan data.

Banyaknya pengguna smartphone berbasis android adalah merupakan sebuah peluang. Pemasar atau perusahaan selalu ingin dapat memberikan layanan yang cepat dan terbaik bagi konsumen aktual dan potensial mereka. Konsumen yang berusaha mencari informasi dan menginginkan kemudahan dalam suatu layanan tertentu. Atas hal itulah maka saat ini bermunculan aplikasi-aplikasi berbasis android yang diperuntukkan bagi kemudahan pada konsumen dalam mendapatkan suatu barang atau layanan tertentu. Sebut saja beberapa aplikasi yang dapat digunakan untuk mencari tiket penerbangan dan pemesanan kamar hotel (traveloka, nusatrip), penawaran jenis produk baru beserta harganya (bhineka, bukalapak, tokopedia, olx). Perdagangan via elektronik yang kita kenal dengan istilah e-commerce sudah bergeser tidak hanya melalui tampilan di layar monitor komputer namun sudah masuk ke dalam perangkat smartphone yang lebih bersifat mobile dan personal. Konsumen dapat dengan cepat dan mudah mencari barang yang diinginkan tanpa harus berpergian. Konsumen juga akan mendapatkan informasi harga yang paling 
rasional baginya. Penggunaan aplikasi yang dijalankan pada smartphone ini biasanya disebut aplikasi mobile.

Kemudahan pemasangan aplikasi mobile di dalam smartphone berbasis android selain merupakan sebuah peluang namun melahirkan tantangan. Kemudahan dalam pemasangan tidak menuntut dukungan teknis yang penuh dari perusahaan penyedia layanan. Aplikasi mobile yang terpasang pada smartphone membuat konsumen memiliki akses informasi yang terus menerus sehingga konsumen memiliki beragam pilihan. Ditambah lagi dengan dukungan internet banking membuat aplikasi mobile ini memudahkan para konsumennya dalam bertransaksi sehingga lebih menghemat waktu mereka ketimbang harus berpergian hanya untuk mendapatkan suatu produk tertentu. Namun di sisi lain pemasangan aplikasi berbasis android kadang mendapat penolakan karena aplikasi tersebut dianggap tidak penting atau aplikasi tersebut membuat masalah pada perangkat smartphone. Kadangkala bagi pengguna smartphone yang jeli, pemasangan aplikasi smartphone dilakukan secara selektif karena ketidakinginan untuk memberikan informasi-informasi pribadi temasuk salah satunya alamat e-mail. Tentunya banyak kendala lain yang harus dihadapi bagi para pengembang aplikasi smartphone agar aplikasi yang sudah dikembangkan dapat diterima.

Strategi yang digunakan para pengembang aplikasi berbasis android dan pemasar yang memungkinkan dapat dijalankannya aplikasi tersebut beragam. Tampilan yang menarik dan kemudahan dalam penggunaan aplikasi tentu menjadi fokus perhatian bagi para pengembang aplikasi. Dilain pihak, para pemasar saat ini tidak hanya mengiklankan produk yang ditawarkan namun juga menginformasikan ketersediaan aplikasi berbasis android bagi para konsumen potensial mereka.

Berdasarkan paparan diatas ada sebuah keinginan untuk mengetahui lebih jauh lagi mengapa seseorang mau mengadopsi atau menggunakan aplikasi mobile berbasis android. Sudah ada beberapa penelitian yang berusaha untuk mengkaji secara akademis mengenai adopsi perangkat lunak/teknologi tertentu. Model yang digunakan dan dikembangkan biasanya menggunakan Technology Acceptance Model (TAM) yang dikembangkan oleh Davis (1989) dengan menggunakan beberapa determinan yang digunakan. Namun penelitian-penelitian yang ada lebih pada melihat karakteristik dari perangkat lunak yang akan diadopsi, sementara alasan untuk mengadopsi lebih pada kemudahan yang dirasakan oleh pengguna ketimbang melihat apakah pengguna memang benar-benar ingin (motivasi) menggunakan perangkat lunak tersebut.

Selain faktor kemudahan kiranya faktor sosial dan resiko juga memberikan andil apakah sebuah perangkat atau aplikasi diterima / digunakan ataukah tidak. Sering kita mendengar bahwa transaksi yang dilakukan secara online rentan akan keamanan. Ketidakyakinan atas keamanan dalam bertransaksi secara online mengakibatkan para konsumen lebih cenderung menggunakan media online sebagai sarana untuk mencari informasi semata ketimbang sekaligus melakukan transaksi. Polularitas sebuah aplikasi turut menentukan tingkat penerimaan aplikasi tersebut. Jangan sampai upaya yang dilakukan oleh para pengembang aplikasi menjadi hal yang sia-sia belaka saat aplikasi yang dikembangkannya tidak dikenal oleh publik.

Permasalah dalam penelitian ini adalah: Apakah kepercayaan dan resiko mempengaruhi sikap dan perilaku dalam menggunakan aplikasi mobile berbasis android?

Tujuan dari penelitian ini adalah untuk membuktikan adanya pengaruh kepercayaan dan resiko terhadap sikap dan perilaku dalam menggunakan atau mengadopsi aplikasi 
mobile berbasis android. Selain itu, dilakukannya penelitian ini untuk mencari alternatif strategi yang dapat digunakan dalam penyebaran aplikasi mobile berbasis android.

Manfaat dari hasil penelitian ini adalah: (1) Dapat mengkonfirmasi dan lebih memperjelas hasil penelitian terdahulu untuk permasalahan serupa, (2) Bagi pelaku bisnis, hasil penelitian ini dapat menjadi sarana untuk lebih memahami sikap dan perilaku konsumen mengenai kepercayaan dan resiko dalam menggunakan aplikasi mobile berbasis Android, (3) Bagi pengembangan ilmu pengetahuan, hasil penelitian ini dapat memperkaya bahan ajar bagi mahasiswa dalam hal memperdalam kepercayaan dan resiko terhadap sikap dan perilaku konsumen dalam menggunakan aplikasi mobile berbasis Android.

\section{KAJIAN TEORI}

Theory of Reasoned Action (TRA) adalah suatu perluasan model dari psikologi sosial yang berkaitan dengan faktor-faktor penentu dari perilaku. Menurut TRA, perilaku seseorang ditentukan oleh niatnya untuk melaksanakan perilaku tersebut (behavioral intention - BI), dan BI secara bersama-sama ditentukan oleh sikap dan norma subjektif dari seseorang atas perilaku. Keinginan berperilaku diukur dari kekuatan niat untuk melaksanakan suatu perilaku yang digambarkan sebagai hal positif atau negatif perorangan. Norma subjektif mengacu pada "persepsi seseorang bahwa suatu hal itu penting untuk dilaksanakan atau tidak dilaksanakan dalam suatu perilaku". Menurut TRA, sikap seseorang terhadap suatu perilaku ditentukan oleh keyakinannya atas perilaku tersebut, konsekuensinya, dan evaluasi. Kepercayaan digambarkan sebagai probabilitas subjektif bahwa setiap melaksanakan perilaku akan mengakibatkan sebuah konsekuensi. TRA adalah suatu model yang umum, tidak menetapkan kepercayaan mata-mata hanya untuk perilaku tertentu. Peneliti-peneliti yang menggunakan TRA harus pertama mengidentifikasi kepercayaan-kepercayaan yang terlihat (Davis, 1989).

Terdapat beberapa model yang dibangun untuk dapat digunakan menganalisis serta memahami faktor-faktor yang mempengaruhi diterimanya penggunaan suatu teknologi, di antaranya yang tercatat dalam berbagai literatur dan referensi hasil riset dibidang teknologi informasi seperti Theory of Reasoned Action (TRA), Theory of Planned Behaviour (TPB), dan Technology Acceptance Model (TAM). Model TAM mengadopsi dari model TRA yaitu teori yang menjelaskan alasan dari diambilnya suatu tindakan, dimana sikap dan perilaku seseorang terhadap sesuatu didasarkan pada reaksi dan persepsi seseorang terhadap hal tersebut. Dalam kaitannya dengan penggunaan suatu teknologi, penerimaan seseorang terhadap suatu teknologi dipengaruhi oleh reaksi dan persepsi pengguna atas teknologi tersebut. Salah satu faktor yang dapat mempengaruhi persepsi pengguna terhadap suatu teknologi adalah kemanfaatan dan kemudahan dalam menggunakan teknologi, sehingga alasan seseorang dalam melihat manfaat dan kemudahan penggunaan IT menjadikan tindakan/perilaku orang tersebut sebagai indikator dalam penerimaan sebuah teknologi. (Davis, 1989)

Model TAM dikembangkan dengan tujuan untuk dapat menjelaskan faktor-faktor utama dari perilaku pengguna komputer atas diterimanya sebuah teknologi. Model ini berdasarkan atas kepercayan (belief), sikap (attitude), keinginan (intention), dan hubungan perilaku pengguna (user behavior relationship) yang dimiliki oleh pengguna (user). (Davis, 1989). Model ini menempatkan faktor sikap dari setiap perilaku pengguna dengan 
dua variabel yaitu : Kemudahan penggunaan (ease of use), dan Kemanfaatan (usefulness). Kedua variabel ini diharapkan dapat menjelaskan aspek keperilakuan pengguna.

Berikut ini adalah model penerimaan teknologi yang dikembangkan oleh Davis:

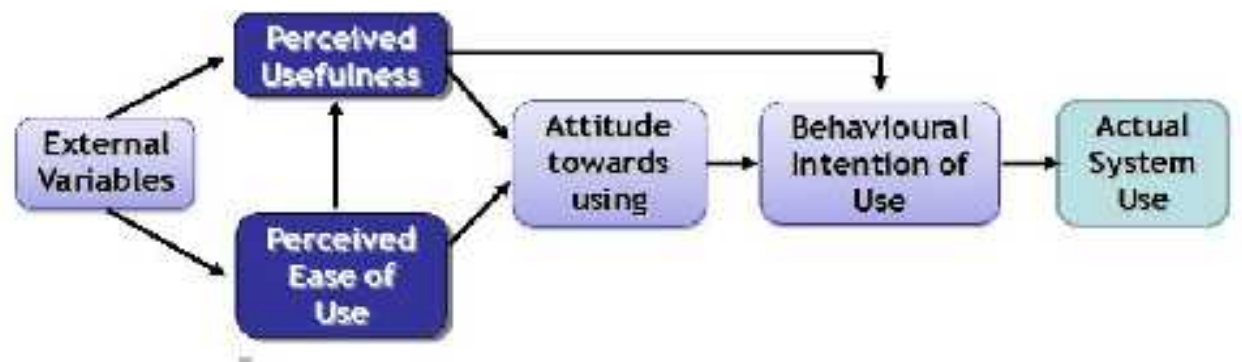

Gambar 1. Model Penerimaan Teknologi

Sumber : Davis (1989)

Penjelasan dari masing-masing konstruk yang digunakan dalam TAM oleh Davis (1989):

1. Perceived ease of use (PEOU). Kemudahan atas penggunaan yang diterima atau dirasakan dapat dijelaskan sebagai sebuah ukuran tentang sejauh mana teknologi tersebut mudah untuk dipahami dan digunakan. Beberapa indikator yang digunakan untuk mengukur kemudahan penggunaan sebuah teknologi adalah: mudah untuk dipelajari, mudah menyelesaikan pekerjaan sesuai yang diinginkan pengguna, mudah untuk dapat meningkatkan keterampilan pengguna,mudah untuk dijalankan.

2. Perceived usefulness (PU). Manfaat yang dirasakan dapat dijelaskan sebagai suatu ukuran tentang tingkat keyakinan dari pengguna bahwa teknologi yang dipakai dapat memberikan manfaat bagi penggunanya. Dimensi tentang kemanfaatan teknologi meliputi: "berguna", yang artinya teknologi menjadikan pekerjaan lebih mudah, bermanfaat, menambah produktivitas. Selanjutnya "efektif", yang artinya dapat meningkatkan efektivitas dan kinerja dalam menyelesaikan suatu pekerjaan.

3. Attitude Toward Using (ATU). Sikap menerima atau menolak menggunakan sebuah teknologi dalam melakukan suatu pekerjaan. Pendapat lain menyatakan bahwa faktor sikap (attitude) sebagai salah satu aspek yang mempengaruhi perilaku individual. Sikap seseorang terdiri atas unsur kognitif/cara pandang, afektif, dan komponenkomponen yang berkaitan dengan perilaku (behavioral components).

4. Behavioral Intention to Use (ITU). Kecenderungan perilaku dari pengguna untuk tetap menggunakan suatu teknologi. Tingkat penggunaan sebuah teknologi pada seseorang dapat dilihat dari perhatiannya terhadap teknologi tersebut, misalnya adanya keinginan untuk menambah perangkat pendukung, memiliki motivasi untuk tetap menggunakan, serta adanya keinginan untuk memotivasi pengguna lain agar menggunakan teknologi yang digunakannya.

5. Actual System Usage (ASU). Suatu keadaan nyata atas penggunaan sebuah system/teknologi. Bentuk pengukuran atas kondisi nyata penggunaan suatu teknologi dapat dilihat dari frekuensi dan durasi waktu penggunaan teknologi tersebut. Seseorang yang puas akan penggunaan teknologi memiliki keyakinan bahwa sistem tersebut mudah untuk digunakan dan akan meningkatkan produktifitas mereka, yang tercermin dari kondisi nyata penggunaan.

The Unified Theory of Acceptance and Use of Technology (UTAUT). Teori ini dikembangkan oleh Vankatesh tahun 2003. Model yang dikembangkan dalam teori ini 
menggunakan konstruk user acceptance dan usage behavior dimana kedua konstruk tersebut dibagi lagi menjadi konstruk performance expectancy, effort expectancy, social influence, dan facilitating conditions. Masing-masing konstruk dalam hubungannya dengan intention to use technology dimoderasi oleh jenis kelamin (gender), usia (age), pengalaman (experience), dan kesediaan untuk menggunakan (voluntary to use). The UTAUT model setidaknya menyediakan lebih dari 70 persen variasi dalam penggunaan teknologi. Sebagaimana disebutkan penggunaan model ini akan membantu dalam membedakan faktor-faktor penting yang mempengaruhi penggunaan suatu teknologi dalam kondisi budaya yang berbeda.

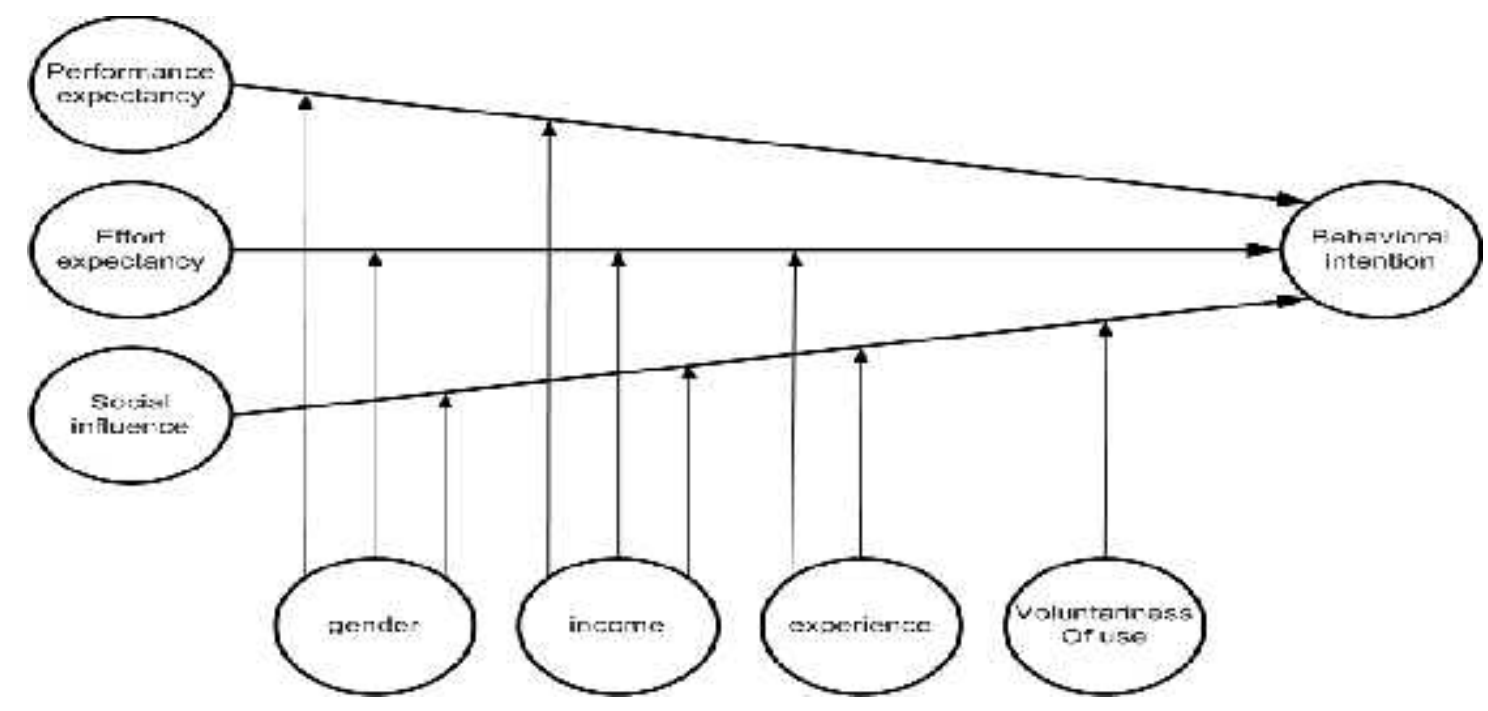

Gambar 2. The UTAUT Model

Sumber : Vankatesh (2003)

Self-Determination Theory. Selft-determination theori (SDT) berpusat pada keyakinan bahwa sifat manusia akan menunjukkan tanda positif terus-menerus, usaha yang dilakukan berulang kali dan komitmen dalam hidup. Orang juga memiliki kebutuhan psikologis bawaan yang merupakan dasar untuk motivasi diri dan integrasi kepribadian. SDT mengidentifikasi tiga kebutuhan bawaan yaitu competence, relatedness dan autonomy. SDT mendukung suatu tindakan pada keterlibatan dalam tindakan yang sudah menjadi pilihan. SDT terdiri dari beberapa subtipe motivasi mulai dari tinggi ke tingkat yang rendah dalam penentuan pilihan. Motivasi merupakan keadaan yang berada dalam diri seseorang untuk berperilaku agar mencapai tujuan tertentu. Vallerand, Deci dan Ryan dalam Li (2011) menyatakan bahwa paling tidak ada tiga kategori motivasi yang dapat diidentifikasikan yaitu motivasi intrinsik (intrinsic motivation), motivasi ekstrinsik (extrinsic motivation) dan amotivation. Motivasi intrinsik berkaitan dengan perilaku yang ditujukan untuk diri sendiri dengan tujuan untuk mendapatkan kesenangan atau kepuasan. Motivasi ektrinsik berkaitan dengan perilaku yang ditujukan untuk beberapa tujuan misalnya untuk menghindari hukuman atau mendapatkan imbalan. Sedangkan amotivasi merupakan kondisi dimana seseorang kehilangan motivasi dan merasa bahwa apa yang dilakukan tidak akan membawa dampak tertentu.

Featherman dan Pavlou dalam Lee (2013) menyatakan bahwa peneliti seharusnya menunjukkan bahwa kepercayaan dan resiko yang diterima adalah faktor kritis dalam 
menjelaskan bagaimana pengguna menerima ICT (Information and Communication Technology) dalam lingkungan e-bisnis. Peneliti lain menyatakan bahwa resiko memiliki peranan sebagai mediasi dalam hubungan antara kepercayaan terhadap perilaku penerimaan. Pavlou dan Gefer dalam Lee (2013) menemukan bahwa kepercayaan konsumen dapat mengurangi resiko yang diterima oleh konsumen yang pada akhirnya dapat meningkatkan transaksi di dalam situasi bisnis-konsumen (B2C). Penelitian lain yang dilakukan oleh Furthermore, Nicolaou dan McKnight (2006) menemukan bahwa faktor kepercayaan secara negatif mempengaruhi resiko yang diterima dan juga secara negatif mempengaruhi intensitas penggunaan dalam pertukaran data di dalam lingkungan bisnis-bisnis (B2B). Lee mengadopsi penelitian yang dilakukan oleh Vankatesh (2003) dengan menggunakan variabel kinerja yang diharapkan (performance expectancy), upaya yang diharapkan (effort expectancy), pengaruh sosial (social influence) dan perilaku (behavioral intention). Hasil penelitian Lee (2013) menunjukkan bahwa kepercayaan memiliki pengaruh positif terhadap perilaku. Sedangkan kepercayaan akan memiliki pengaruh yang negatif terhadap perilaku saat dimediasi oleh variabel resiko yang diterima. Lee juga menemukan bahwa faktor pengaruh sosial memiliki pengaruh yang positif terhadap perilaku.

Penelitian lainnya yang dilakukan oleh $\mathrm{Wu}$ (2015) mencoba untuk menyelidiki secara menyeluruh tentang fakor motivasi, kepercayaan dan resiko. Perilaku dari konsumen di online shopping diamati dengan menggunakan model-model berbasis sifatsifat personal konsumen, resiko yang diterima dan penerimaan teknologi. Dari penelitian ini, Wu menemukan bahwa resiko yang diterima mempengaruhi kepercayaan. Penelitian ini juga menghasilkan bahwa variabel sikap memediasi hubungan antara kepercayaan dan resiko yang diterima terhadap perilaku.

Penelitian yang dilakukan oleh Javadi, dkk. (2012) mencoba untuk menganalisis faktor-faktor yang mempengaruhi perilaku belanja online konsumen. Penelitian ini melihat resiko yang diterima sebagai sejumlah resiko yang diterima oleh konsumen dalam suatu keputusan pembelian. Semakin tinggi resiko yang akan diterima maka akan membuat konsumen semakin menolak melakukan pembelian. Javadi, dkk. membagi resiko ke dalam beberapa bagian yaitu resiko finansial, resiko produk, resiko kenyamanan dan resiko tidak dihantar. Variabel sikap sebagai variabel mediasi dalam pengaruhnya terhadap perilaku.

\section{Hipotesis}

H1 : resiko yang diterima/dirasakan berpengaruh negatif dan signifikan terhadap tingkat kepercayaan.

$\mathrm{H} 2$ : tingkat kepercayaan berpengaruh positif dan signifikan terhadap sikap.

$\mathrm{H} 3$ : tingkat resiko yang diterima/dirasakan berpengaruh negatif dan signifikan terhadap sikap.

H4 : tingkat kepercayaan berpengaruh positif dan signifikan terhadap perilaku

H5 : tingkat resiko yang diterima/dirasakan berpengaruh negatif dan signifikan terhadap perilaku.

H6 : sikap berpengaruh positif dan signifikan terhadap perilaku.

H7 : aspek sosial berpengaruh positif dan signifikan terhadap perilaku.

Variabel Penelitian. Variabel penelitian adalah konsep abstrak untuk diamati. Menurut Ghozali (2004), konsep abstrak dapat diukur langsung atau tidak langsung. Konsep abstrak yang dapat diukur langsung disebut observed variabel atau manifest. Sedangkan konsep yang tidak dapat diukur langsung disebut unobserved variabel atau konstruk atau 
latent. Ada dua jenis variabel laten yaitu variabel exogen (independen) dan variabel endogen (dependen). Dalam penelitian ini yang coba peneliti amati adalah kepercayaan, resiko, sikap, perilaku dan sosial yang merupakan unobserved variabel, konstruk atau latent. Variabel-variabel tersebut diukur dengan menggunakan seperangkat pernyataan. Terdapat tiga variabel exogen laten yaitu resiko, kepercayaan dan sosial. Terdapat dua variabel endogen laten yaitu sikap dan perilaku.

Definisi Operasional.Setiap variabel yang akan digunakan di dalam penelitian harus dapat dijabarkan secara operasional agar tepat dalam pengukurannya. Definisi operasional dari variabel yang digunakan dalam penelitian ini adalah: Pertama. Kepercayaan, merupakan tingkat keyakinan, kemampuan, integritas dan niat baik atas layanan atau tekonolgi baru yang disediakan oleh perusahaan atau pemasar yang ada dalam diri pengguna/konsumen. Dalam penelitian ini variabel kepercayaan diukur dengan menggunakan tiga pernyataan yang dikembangkan oleh Lee (2013). Kedua. Resiko merupakan tingkat dimana pengguna percaya bahwa menggunakan layanan atau teknologi baru yang disediakan dapat menyebabkan kerugian. Dalam penelitian ini variabel resiko diukur dengan menggunakan lima pernyataan yang dikembangkan oleh Lee (2013). Ketiga. Sikap merupakan niat seseorang untuk menggunakan atau tidak menggunakan layanan atau teknologi baru yang disediakan. Dalam penelitian ini variabel sikap diukur dengan menggunakan dua pernyataan yang dikembangkan oleh Javadi dkk (2012). Keempat. Perilaku merupakan pernyataan kesediaan konsumen untuk menggunakan layanan atau teknologi baru yang sediakan oleh pemasar. Dalam penelitian ini variabel perilaku diukur dengan menggunakan tiga pernyataan yang dikembangkan oleh Vankatesh (2003). Kelima. Sosial merupakan keyakinan yang diterima atau dirasakan oleh pengguna bahwa mereka seharusnya menggunakan layanan atau teknologi yang disediakan. Dalam penelitian ini variabel sosial diukur dengan menggunakan empat pernyataan yang dikembangkan oleh Vankatesh (2003).

\section{Model Penelitian}

Berdasarkan paparan teori di atas maka dalam penelitian ini penulis mengajukan model penelitian sebagai berikut:

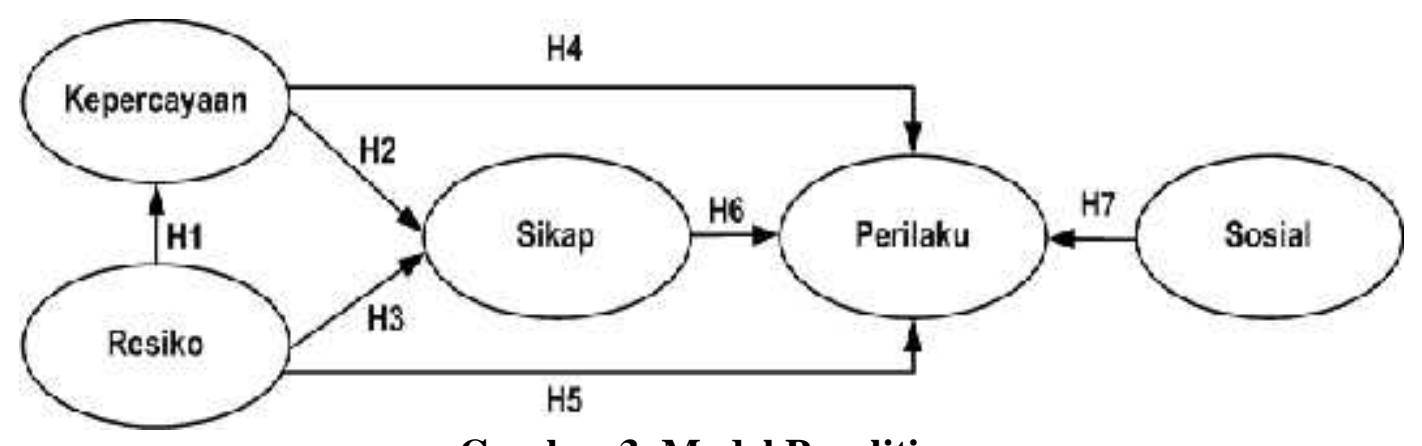

Gambar 3. Model Penelitian

\section{METODE}

Penelitian ini adalah penelitian kuantitatif dengan menggunakan teknik survey, yaitu menyebarkan kuesioner. Hipotesis diajukan untuk dibuktikan kebenarannya mengenai 
Pengaruh Kepercayaan dan Resiko Terhadap Sikap dan Perilaku Dalam Menggunakan Aplikasi Mobile Berbasis Android.

Populasi dan Teknik Pengambilan Sampel. Populasi dari penelitian ini adalah seluruh subjek atau individu yang menggunakan aplikasi mobile berbasis android di Palembang. Sampel digunakan dengan alasan bahwa jumlah populasi pengguna aplikasi mobile berbasis android tidak diketahui dengan pasti atau yang biasa dikenal sebagai nonprobability methods. Menurut Crask, Fox dan Stout (1995) pengertian dari nonprobability sampling methods adalah "Every member of the sampling frame does not have a non zero chance of being selected." Cara yang digunakan untuk pemilihan sampel pada nonprobability sampling methods dalam penelitian ini adalah convenience sampel dan judgment sampling. Menurut Crask, Fox dan Stout (1995), Convenience sampel adalah "Nonprobalility sampel in which the sampled members are chosen because they are easily accessible." Sedangkan, judgment sampling adalah "researcher subjectively chooses sample member who are belived to be representative of the target population or particularly knowledgeable about the topic being studied." Jumlah responden yang digunakan dalam penelitian ini adalah 100 orang didasarkan dari pendapat Roscoe (1975) dalam Sekaran (2000) yang menyatakan bahwa rule of thumb untuk menentukan ukuran sampel adalah lebih besar dari 30 dan kurang dari 500 tepat untuk banyak penelitian.

Teknik Pengumpulan Data. Untuk mengumpulkan data penelitian digunakan kuesioner. Kuesioner terdiri dari pernyataan tentang penilaian atas penggunaan aplikasi mobile berbasis android secara keseluruhan. Kuesioner ini juga berisi tentang penilaian responden mengenai hal-hal yang membuat responden tersebut memilih atau menolak menggunakan aplikasi mobile berbasis android. Pilihan jawaban untuk setiap pernyataan menggunakan tipe jawaban skala Likert dengan 7 kategori jawaban yaitu: sangat tidak setuju sekali (1), sangat tidak setuju (2), tidak setuju (3), netral (4), setuju (5), sangat setuju (6) dan sangat setuju sekali (7).

Metode Analisis Data. Dalam penelitian ini penulis menggunakan metode analisis data SEM. Structural Equation Model (SEM) merupakan sekumpulan teknik-teknik statistikal yang memungkinkan pengujian sebuah rangkaian hubungan secara simultan. Model hubungan yang dibangun dapat antara satu atau beberapa variabel dependen dengan satu atau beberapa variabel independen. Masing-masing variabel dependen dan independen dapat berbentuk faktor (atau construct yang dibangun dari beberapa variabel indikator). Sesungguhnya pemodelan dengan persamaan struktural telah dikenal luas dalam penelitian-penelitian manajemen, melalui berbagai macam nama antara lain: causal modeling, causal analysis simultaneous equations modeling atau analisis struktur kovarian.

Terdapat dua model SEM yang digunakan saat ini yaitu SEM berbasis covariance atau dikenal Covariance Based SEM dan SEM yang berbasis variance atau sering disebut Component Based SEM. Covariance Based SEM mengunakan software AMOS dan LISREL sedangkan Component Based SEM yang mempergunakan software seperti SmartPLS dan PLS Graph. Perbedaan utama antara Covariance Based SEM dan Component Based SEM adalah pada Covariance Based SEM model yang dibentuk harus dikembangkan landasan teori yang kuat karena memang tujuannya adalah untuk melakukan konfirmasi antara model dengan data empirisnya. Sedangkan Component Based SEM menitikberatkan pada model yang digunakan untuk prediksi sehingga 
dukungan teori yang kuat tidak begitu penting. Bila tujuan dari penelitian adalah ingin mengkonfirmasi suatu model yang dibangun berdasarkan pada teori, maka sebaiknya menggunakan Covariance Based SEM. Sedangkan bila ingin membuat model prediksi dan dasar teori tidak begitu kuat, maka sebaiknya menggunakan Component Based SEM atau juga dikenal Partial Least Square (PLS) (Ghozali, 2006). Dalam penelitian ini digunakan metode analisis Component Based SEM atau dikenal dengan Partial Least Square (PLS), yang model evaluasinya dibuat berdasarkan prediksi yang mempunyai sifat non parametrik. PLS adalah analisis persamaan struktural (SEM) berbasis varian yang secara simultan melakukan pengujian model pengukuran sekaligus pengujian model struktural. Model pangukuran digunakan untuk uji validitas dan reliabilitas, sedangkan model struktural digunakan untuk uji kausalitas. Beberapa literatur menyebutkan bahwa PLS merupakan alat yang handal untuk menguji model prediksi karena memiliki beberapa keunggulan yaitu (Jogiyanto, 2011): a). Tidak mendasarkan pada berbagai asumsi, b). Dapat digunakan untuk memprediksi model dengan landasan teori yang lemah. c). Dapat digunakan pada data yang mengalami "penyakit" asumsi klasik. d). Dapat digunakan untuk ukuran sampel kecil. e). Dapat digunakan untuk konstruk formatif dan reflektif. Tahap-tahap dalam model evaluasi PLS adalah sebagai berikut (Jogiyanto, 2011):

Model pengukuran (outer model). Merupakan model untuk menilai validitas dan reliabilitas. Parameter yang digunakan adalah validitas konvergen, validitas diskriminan, composite reliability dan cronbach's alpha termasuk didalamnya adalah $\mathrm{R}^{2}$ sebagai parameter ketepatan model prediksi. Uji validitas dilakukan untuk mengetahui kemampuan instrumen penelitian mengukur apa yang seharusnya diukur. Sedangkan uji reliabilitas digunakan untuk mengukur konsistensi alat ukur dalam mengukur suatu konsep atau dapat juga digunakan untuk mengukur konsistensi responden dalam menjawab item pernyataan dalam kuesioner. Validitas konvergen berhubungan dengan prinsip bahwa pengukur-pengukur dari suatu konstruk seharusnya berkorelasi tinggi. Validitas konvergen terjadi jika skor yang diperoleh dari dua instrumen yang berbeda yang mengukur konstruk yang sama memiliki korelasi tinggi (Jogiyanto, 2011). Validitas diskriminan berhubungan dengan prinsip bahwa pengukur-pengukur konstruk yang berbeda seharusnya tidak berkorelasi dengan tinggi. Validitas diskriminan terjadi bila dua instrumen yang berbeda yang digunakan untuk mengukur dua konstruk yang diprediksi tidak berkorelasi menghasilkan skor yang memang tidak berkorelasi (Jogiyanto, 2011). Berikut adalah parameter uji validitas dalam Model Pengukuran PLS.

Tabel 1. Parameter Uji Validitas dalam Model Pengukuran PLS

\begin{tabular}{lll}
\hline Uji validitas & Parameter & Rule of Thumbs \\
\hline Konvergen & $\begin{array}{l}\text { Faktor loading } \\
\text { Average variance extracted } \\
\text { (AVE) }\end{array}$ & Lebih dari 0,7 \\
& Lebih dari 0,5 \\
Communality & Lebih dari 0,5 \\
Diskriminan & Akar AVE dan Korelasi & Akar AVE > korelasi \\
& variabel laten & variabel laten \\
& Cross loading & Lebih dari 0,7 dalam satu \\
& & variabel \\
\hline
\end{tabular}

Sumber: Jogiyanto (2011) diadaptasi dari Chin (1995) 
Uji reliabilitas dalam PLS dapat menggunakan dua metode yaitu cronbach's alpha dan composite reliability. Rule of thumb untuk composite reliability harus lebih besar dari 0,7 meskipun nilai 0,6 masih dapat diterima. Menurut Cooper, sesungguhnya uji konsistensi internal tidak mutlak untuk dilakukan jika validitas konstruk telah terpenuhi, karena konstruk yang valid adalah konstruk yang reliabel, sebaliknya konstruk yang reliabel belum tentu valid (Jogiyanto, 2011).

Model struktural (inner model). Model struktural dalam PLS dievaluasi dengan menggunakan $\mathrm{R}^{2}$ untuk konstruk dependen, nilai koefisien path atau $t$-values tiap path untuk uji signifikansi antar konstruk dalam model struktural. Semakin tinggi nilai $\mathrm{R}^{2}$ berarti semakin baik model prediksi dari model penelitian yang diajukan. Nilai koefisien path atau inner model menunjukkan tingkat signifikansi dalam pengujian hipotesis. Skor koefisien path atau inner model yang ditunjukkan oleh nilai T-statistic harus diatas 1,96 untuk hipotesis dua ekor (two tailed) dan diatas 1,64 untuk hipotesis satu ekor (one tailed) untuk pengujian hipotesis pada alpha 5 persen dan power 80 persen (Hair dalam Jogiyanto 2011). Analisis jalur (path analysis) adalah pengembangan dari model regresi yang digunakan untuk menguji kesesuaian yang ada antara matrik korelasi. Nilai regresi yang diprediksi dari model dibandingkan dengan matrik korelasi. Perbandingan antara matrik korelasi dengan nilai regresi dipilih berdasarkan nilai yang terbaik (goodness of fit). (Ghozali:2009). Model merupakan dasar untuk memperkirakan kekuatan hubungan kausalitas yang tergambar dalam model jalur (path model). Korelasi antara dua konstruk digambarkan sebagai jalur panah yang mengikuti aturan (Ghozali:2009) yaitu: (a) Setelah maju ke depan dengan anak panah maka jalur tidak dapat bergerak ke belakang lagi, (b) Jalur tidak dapat bergerak menuju konstruk yang sama lebih dari sekali, (c) Jalur hanya berisi satu kurva anak panah (yang menggambarkan regresi). Selanjutnya, Hair,et.al. dalam Ghozali (2009) mengajukan tahapan dalam pemodelan dan analisis persamaan struktural menjadi enam langkah yaitu: (a) Mengembangkan model secara teoritis, (b) Menyusun diagram jalur (path diagram), (c) Mengubah persamaan jalur menjadi persamaan structural, (d) Memilih matrik input untuk analisis data, (e) Menilai indentifikasi model, (f) Mengevaluasi estimasi model.

\section{HASIL DAN PEMBAHASAN}

Data Deskriptif. Dalam penelitian ini menggunakan sampel sebanyak 100 responden. Berikut ini adalah identitas responden atau deskriptif data dari sampel yang digunakan dalam penelitian ini.

Tabel 2. Identitas Responden

\begin{tabular}{|c|c|c|c|c|c|c|}
\hline \multirow{2}{*}{$\begin{array}{l}\text { Pernyataan } \\
\text { Frekuensi } \\
\text { menggunakan } \\
\text { internet }\end{array}$} & \multicolumn{5}{|c|}{ Jawaban Responden } & \multirow{2}{*}{ Jumlah } \\
\hline & Jarang & $\begin{array}{l}\text { Kadang- } \\
\text { kadang }\end{array}$ & Sering & $\begin{array}{l}\text { Setiap } \\
\text { hari }\end{array}$ & - & \\
\hline & 4 & 11 & 26 & 59 & - & 100 \\
\hline $\begin{array}{l}\text { Frekuensi } \\
\text { berbelanja via } \\
\text { internet }\end{array}$ & Jarang & $\begin{array}{l}\text { Kadang- } \\
\text { kadang }\end{array}$ & Sering & $\begin{array}{l}\text { Setiap } \\
\text { hari }\end{array}$ & - & \\
\hline & 25 & 52 & 22 & 1 & - & 100 \\
\hline $\begin{array}{l}\text { Koneksi yang } \\
\text { digunakan }\end{array}$ & $\begin{array}{l}\text { Berlangg } \\
\text { an-an }\end{array}$ & $\begin{array}{l}\text { Wifi } \\
\text { kantor/kampus }\end{array}$ & $\begin{array}{l}\text { Wifi } \\
\text { tempat }\end{array}$ & - & - & \\
\hline
\end{tabular}


Widyartono dan Tyra: Pengaruh Kepercayaan dan Resiko erhadap Sikap dan Perilaku...

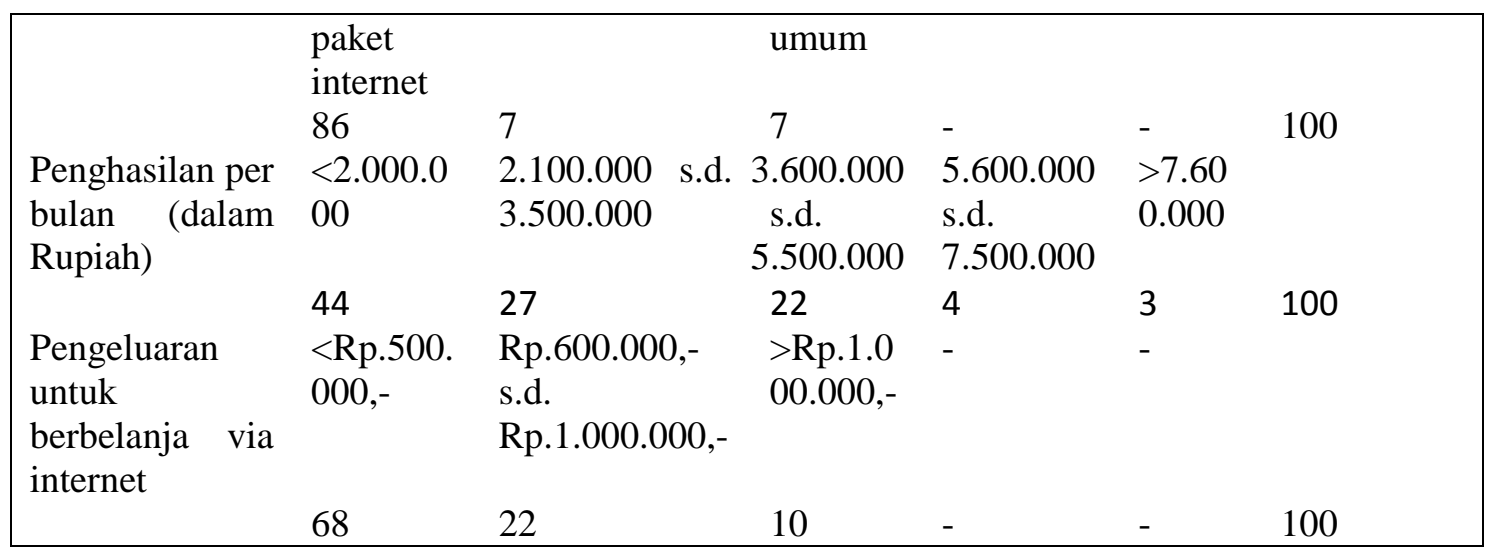

Sumber: data olahan.

Outer Model (Model Pengukuran). Tahap awal dalam pengujian ini adalah untuk melihat apakah indikator-indikator yang digunakan benar-benar bebas dari kesalahan (error). Untuk itu digunakan bantuan program SmartPLS untuk menemukan nilai loading factor, composite reliability, Average variance extracted (AVE), validitas diskriminan dan cross loading.

Convergent validity dari model pengukuran yang menggunakan indikator reflektif dapat dilihat dari nilai korelasi antara score item/indikator dengan score konstruknya. Indikator dianggap reliable bila nilai korelasi diatas 0,7 namun pada riset tahap pengembangan nilai 0,5 sampai 0,6 masih dapat diterima. Pada tahap awal pengukuran didapat hasil untuk indikator yang merefleksikan resiko terdapat dua indikator yang nilai loading-nya berada di bawah 0,5 Setelah kedua indikator tersebut dikeluarkan hasil dari loading factor adalah sebagai berikut:

Tabel 3. Convergent Validity

\begin{tabular}{lll}
\hline Indikator & Konstruk & Loading Factor \\
\hline at1 & sikap & 0,894 \\
at2 & sikap & 0,706 \\
bh1 & perilaku & 0,835 \\
bh2 & perilaku & 0,905 \\
bh3 & perilaku & 0,848 \\
rs3 & resiko & 0,804 \\
rs4 & resiko & 0,774 \\
rs5 & resiko & 0,747 \\
sn1 & aspek sosial & 0,840 \\
sn2 & aspek sosial & 0,693 \\
sn3 & aspek sosial & 0,740 \\
sn4 & aspek sosial & 0,593 \\
tr1 & kepercayaan & 0,802 \\
tr2 & kepercayaan & 0,808 \\
tr3 & kepercayaan & 0,844 \\
\hline
\end{tabular}

Sumber: data olahan. 
Rule of thumb untuk composite reliability harus lebih besar dari 0,7 meskipun nilai 0,6 masih dapat diterima. Sedangkan rule of thumb untuk Average variance extracted (AVE) harus lebih dari 0,5. Berdasarkan hasil pengolahan data diperoleh nilai sebagai berikut :

Tabel 4. Composite Reliability

\begin{tabular}{lc}
\hline & Composite Reliability \\
\hline aspek sosial & 0,811 \\
kepercayaan & 0,859 \\
perilaku & 0,898 \\
resiko & 0,819 \\
sikap & 0,784 \\
\hline
\end{tabular}

Sumber: data olahan

Tabel 5. Average Variance Extracted (AVE)

\begin{tabular}{ll}
\hline & AVE \\
\hline aspek sosial & 0,521 \\
kepercayaan & 0,669 \\
perilaku & 0,746 \\
resiko & 0,602 \\
sikap & 0,648 \\
\hline
\end{tabular}

Sumber: data olahan

Validitas diskriminan indikator reflektif dapat dilihat dari cross loading antara nilai indikator dengan nilai konstruknya, berikut hasil yang diperoleh dari output Smart PLS.

Tabel 6. Validitas diskriminan

\begin{tabular}{lrrrrr}
\hline & aspek sosial & kepercayaan & perilaku & \multicolumn{1}{l}{ resiko } & \multicolumn{1}{c}{ sikap } \\
\hline at1 & 0,438 & 0,507 & 0,538 & $-0,377$ & 0,894 \\
at2 & 0,582 & 0,352 & 0,354 & $-0,124$ & 0,706 \\
bh1 & 0,317 & 0,359 & 0,835 & $-0,064$ & 0,516 \\
bh2 & 0,259 & 0,347 & 0,905 & $-0,159$ & 0,447 \\
bh3 & 0,463 & 0,400 & 0,848 & $-0,219$ & 0,500 \\
rs3 & $-0,213$ & $-0,274$ & $-0,161$ & 0,804 & $-0,328$ \\
rs4 & $-0,127$ & $-0,186$ & $-0,110$ & 0,774 & $-0,222$ \\
rs5 & 0,014 & $-0,216$ & $-0,115$ & 0,747 & $-0,216$ \\
sn1 & 0,840 & 0,451 & 0,385 & $-0,185$ & 0,574 \\
sn2 & 0,693 & 0,256 & 0,261 & $-0,036$ & 0,269 \\
sn3 & 0,740 & 0,381 & 0,283 & $-0,088$ & 0,483 \\
sn4 & 0,593 & 0,392 & 0,213 & $-0,116$ & 0,366 \\
tr1 & 0,407 & 0,802 & 0,365 & $-0,225$ & 0,425 \\
tr2 & 0,400 & 0,808 & 0,331 & $-0,188$ & 0,434 \\
tr3 & 0,452 & 0,844 & 0,358 & $-0,308$ & 0,476 \\
\hline
\end{tabular}

Sumber: data olahan 
Dari tabel diatas terlihat bahwa nilai korelasi konstruk aspek sosial dengan indikatornya lebih tinggi jika dibandingkan dengan nilai korelasi kontruk dengan indikator lainnya. Hal ini juga ditampilkan dari indikator-indikator lain yang menunjukkan nilai korelasi lebih tinggi terhadap konstruknya masing-masing. Ini menunjukkan bahwa konstruk laten memprediksi indikator pada blok mereka yang lebih baik dibandingkan dengan indikator di blok lainnya.

Menurut Cooper, sesungguhnya uji konsistensi internal tidak mutlak untuk dilakukan jika validitas konstruk telah terpenuhi, karena konstruk yang valid adalah konstruk yang reliabel, sebaliknya kontruk yang reliabel belum tentu valid (Jogiyanto, 2011).

Inner Model (Model Struktural). Langkah selanjutnya setelah melakukan uji validitas instrumen adalah dengan melakukan evaluasi model struktural. Tahap evaluasi atas model struktural ini dapat dilakukan secara individu dan simultan. Model struktural dievaluasi dengan menggunakan $R$-square untuk konstruk dependen. Dalam menilai model dengan PLS dimulai dengan melihat $R$-square untuk setiap variabel laten dependen. Interpretasi yang dilakukan sama dengan interpretasi pada regresi (Ghozali, 2008:26). Evaluasi model struktural diawal dengan melihat signifikansi hubungan antara model dengan nlai tstatistic yang dihasilkan lewat proses bootstrap. Model struktural yang diujikan adalah sebagai berikut:

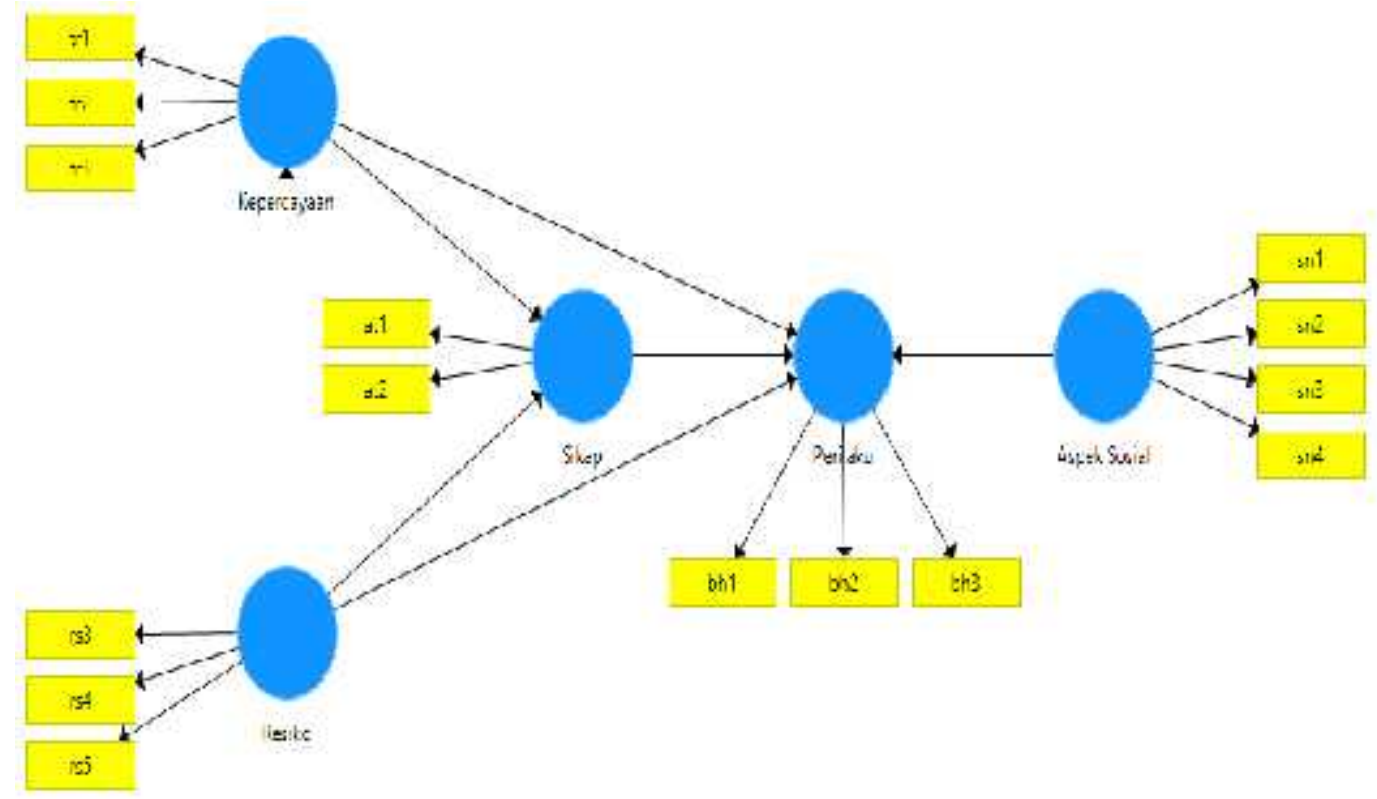

Gambar 4. Model Struktural

Hasil dari pengujian model struktural disajikan dalam tabel di bawah ini:

Tabel 7. Nilai $\mathrm{R}^{2}$

\begin{tabular}{l|l}
\hline & R Square \\
\hline Kepercayaan & 0,088 \\
Perilaku & 0,347 \\
Sikap & 0,331 \\
\hline
\end{tabular}

Sumber : data olahan 
Widyartono dan Tyra: Pengaruh Kepercayaan dan Resiko erhadap Sikap dan Perilaku...

Tabel 8. Nilai $F^{2}$

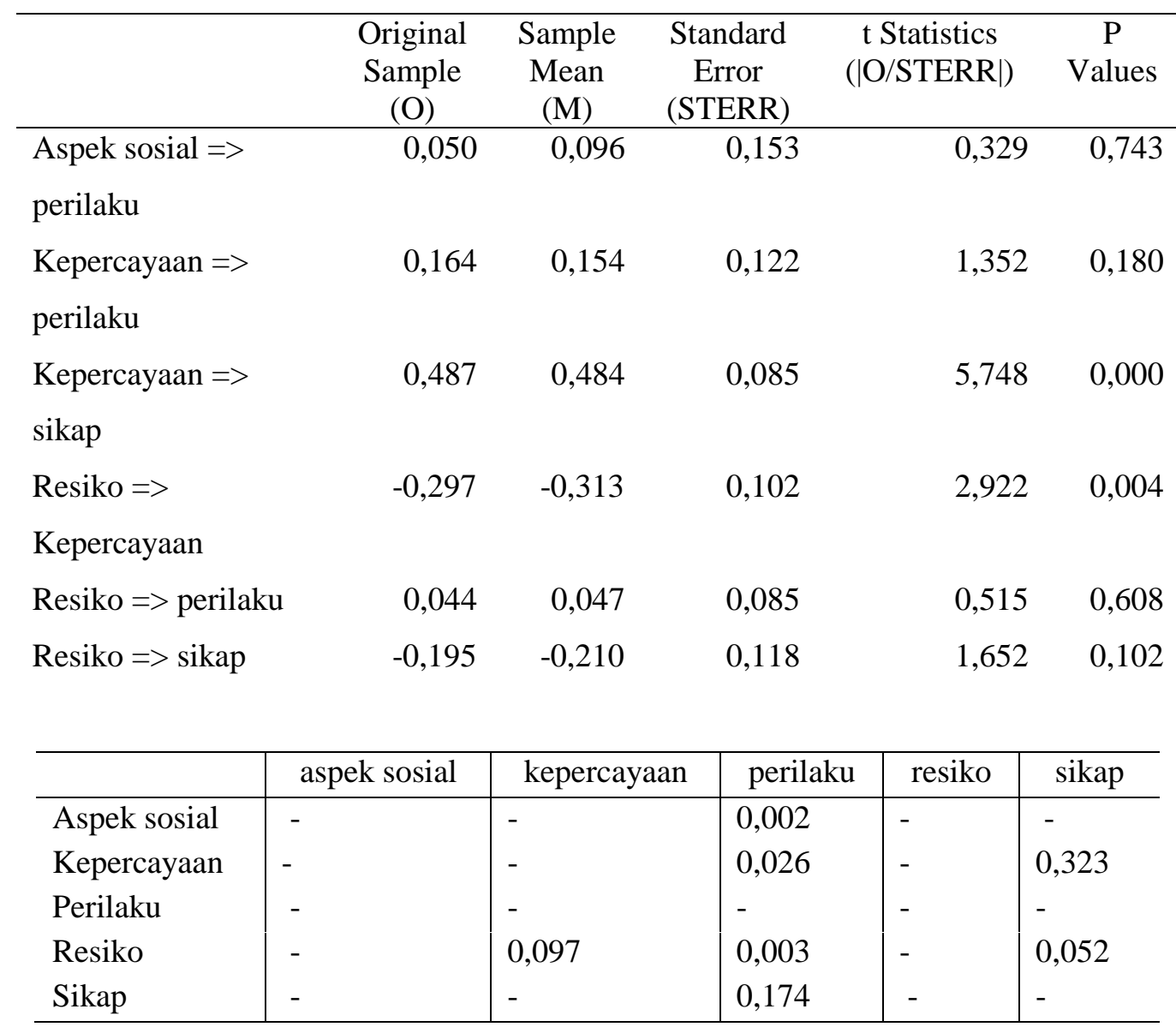

Sumber: data olahan

Tabel 9. Mean, STDEV, t-Values, P-Values 


\begin{tabular}{llllll} 
Sikap $=>$ perilaku & 0,463 & 0,437 & 0,110 & 4,211 & 0,000 \\
\hline
\end{tabular}

Sumber: data olahan

Berdasarkan nilai t-statistics yang dibandingkan dengan nilai t-tabel $(1,96)$ dan nilai P-Value maka diperoleh nilai signifikan untuk pengaruh antara kepercayaan terhadap sikap, resiko terhadap kepercayaan dan sikap terhadap perilaku. Selanjutnya diuji juga apakah kepercayaan dan sikap sungguh merupakan variabel mediasi antara resiko terhadap perilaku. Pengujian ini dilakukan dengan melihat pengaruh langsung variabel resiko terhadap perilaku dan membandingkannya dengan pengaruh tidak langsung variabel resiko terhadap perilaku melalui variabel sikap dan kepercayaan. Hasil pengujian pengaruh langsung dan tidak langsung adalah sebagai berikut:

Tabel 10. Variabel Resiko Terhadap Sikap Dengan Mediasi Kepercayaan

\begin{tabular}{lll}
\hline & Direct Effect & Indirect Effect \\
\hline resiko -> sikap & $-0,195$ & $-0,145$ \\
resiko -> kepercayaan & $-0,297$ & \\
kepercayaan -> sikap & 0,487 & \\
\hline
\end{tabular}

Sumber: data olahan

Tabel 11. Variabel Resiko Terhadap Perilaku Dengan

Mediasi Kepercayaan

\begin{tabular}{lll}
\hline & Direct Effect & Indirect Effect \\
\hline resiko -> perilaku & 0,044 & $-0,049$ \\
\hline resiko -> kepercayaan & $-0,297$ & \\
\hline kepercayaan -> perilaku & 0,164 & \\
\hline Sumber : data olahan &
\end{tabular}

Sumber : data olahan

Tabel 12. Variabel Resiko Terhadap Perilaku Dengan Mediasi sikap

\begin{tabular}{lll}
\hline & Direct Effect & Indirect Effect \\
\hline resiko $->$ perilaku & 0,044 & $-0,090$ \\
resiko $->$ sikap & $-0,195$ & \\
sikap $->$ perilaku & 0,463 & \\
\hline
\end{tabular}

Sumber : data olahan

Berdasarkan hasil pengujian variabel mediasi diatas terlihat bahwa variabel kepercayaan benar-benar sebagai variabel yang memediasi pengaruh antara resiko terhadap sikap. Berikutnya adalah melakukan pengujian apakah variabel sikap memediasi hubungan antara variabel kepercayaan terhadap perilaku. Hasil dari pengujiannya adalah sebagai berikut:

Tabel 13. Variabel kepercayaan terhadap perrilaku dengan mediasi sikap

\begin{tabular}{l|l|l}
\hline & Direct Effect & Indirect Effect \\
\hline $\begin{array}{l}\text { kepercayaan -> } \\
\text { perilaku }\end{array}$ & 0,164 & 0,225 \\
\hline
\end{tabular}




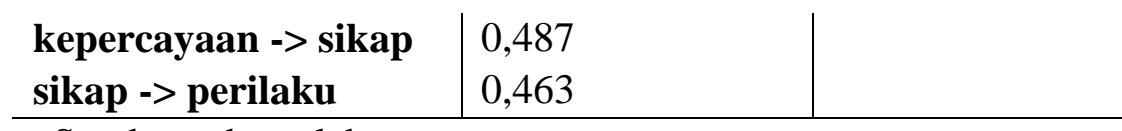

Sumber : data olahan

Diperoleh hasil dari pengujian bahwa nilai efek tidak langsung memiliki nilai lebih besar dibandingkan nilai tidak langsung. Hal ini membuktikan bahwa sikap memang merupakan variabel mediasi antara kepercayaan terhadap perilaku.

\section{PENUTUP}

Simpulan. Berdasarkan hasil pengujian data terbukti bahwa variabel kepercayaan dan sikap memang merupakan variabel mediasi hubungan antara resiko dengan sikap dan perilaku. Dalam penelitian ini terbukti bahwa resiko merupakan faktor yang membentuk sikap dan perilaku seseorang dalam menggunakan aplikasi mobile berbasis android. Resiko yang dirasakan oleh para pengguna android sering berkaitan dengan akses atas informasi yang ada pada perangkat android yang bisa jadi informasi tersebut adalah privasi bagi mereka. Resiko yang mungkin akan dirasakan oleh para pengguna android selain informasi private yang akan diakses adalah kinerja dari perangkat android yang dirasa akan melambat. Hal-hal tersebut yang mungkin dirasakan oleh para pengguna android sebagai sebuah resiko. Dalam penelitian ini terbukti resiko berbanding terbalik dengan kepercayaan dan sikap, bahwa semakin tinggi resiko yang dirasakan akan menurunkan kepercayaan atas sebuah aplikasi dan sikap atas aplikasi tersebut.

Faktor kepercayaan dapat membentuk sikap seseorang dan perilaku seseorang dalam menggunakan atau tidak menggunakan sebuah aplikasi. Dalam penelitian ini terbukti bahwa kepercayaan berbanding lurus dengan sikap dan sikap berbanding lurus dengan perilaku dalam menggunakan aplikasi berbasis android. Faktor kerpercayaan disini adalah bahwa para pengguna android yakin bahwa aplikasi mobile yang terpasang membantu mereka dalam menjalankan sebuah transaksi dan tidak melanggar privasi mereka. Dalam sebuah bisnis memang kepercayaan atas suatu layanan adalah hal yang penting. Sikap yang positif atas sebuah layanan dalam hal ini adalah kemampuan dari aplikasi berbasis android untuk berkinerja sesuai dengan yang diharapkan akan memperkuat perilaku seseorang atas aplikasi tersebut.

Rekomendasi. Penelitian ini masih menggunakan model penelitian yang masih harus dikembangkan lagi. Terlihat bahwa faktor sosial dalam penelitian ini tidak menunjukkan hasil yang signifikan berpengaruh terhadap perilaku dalam menggunakan atau tidak menggunakan sebuah aplikasi atau teknologi tertentu. Tentunya hal ini agak tidak sesuai dengan penelitian-penelitian sebelumnya yang menunjukkan bahwa faktor sosial memiliki pengaruh terhadap perilaku seseorang dalam menggunakan sebuah aplikasi/teknologi. Kiranya instrumen-instrumen yang digunakan dalam pengukuran faktor sosial di dalam adopsi sebuah teknologi dapat dikembangkan lagi kedepannya. Penelitian ini juga tidak mengukur faktor resiko yang dirasakan secara lebih dalam. Diharapkan bahwa dalam penelitian berikutnya dapat diperdalam lagi faktor resiko yang akan diterima dan bagaimana sikap pengguna atas aspek-aspek resiko yang berbeda.

Dalam menggunakan sebuah aplikasi/teknologi faktor resiko dan kepercayaan merupakan hal yang perlu dan penting untuk menjadi perhatian. Saat pengguna merasa privasinya terganggu tentunya ia akan menolak menggunakan aplikasi/teknologi tersebut. 
Perusahaan atau industri yang hendak meningkatkan layanan yang diberikan dengan menggunakan aplikasi berbasis android seharusnya paham atas persepsi resiko yang ada di benak para pengguna aplikasi mereka. Memberikan informasi yang jelas tentang apa saja yang akan diterima, dirasakan, besar penggunaan ruang penyimpanan dalam perangkat android sudah semestinya diinformasikan. Perusahaan atau industri yang akan menggunakan aplikasi berbasis android dapat mengembangkan aplikasi dengan penggunaan kapasitas memory yang paling efisien. Perusahaan juga harus menunjukkan komitmennya untuk tetap menjaga informasi-informasi yang bersifat privasi dari para pengguna aplikasi mereka.

\section{DAFTAR RUJUKAN}

Crask, M., Fox, R. J., \& Stout, R. G. (1995) Marketing Research: Principles and Applications. Prentice Hall: New Jersey.

Davis F.D., Bagozzi, R.P. and Warshaw, P.R. (1989) User Acceptance of Computer Technology. A Comparison of Two Theoretical Models. Management Science, 35 (8), pp. 982-1003.

Davis, F.D. (1989) "Perceived usefulness, perceived ease of use, and user acceptance of information technology". MIS Quarterly, 13 (3): 318-340.

Davis, F.D. (1993) "User acceptance of information technology: system characteristics, user perceptions and behavioural impacts". International Journal of Man-Machine Studies, 38: 475-487.

Davis, F.D. dan Venkatesh, V. (2004) 'Toward Preprototype User Acceptance Testing of New Information Systems: Implications for Software Project Management”. IEEE Transactions on Engineering Management, 51.

Ghozali, Imam. (2006) Structural Equation Model Metode Alternatif dengan Partial Least Square. Badan Penerbit Universitas Diponegoro.

Ghozali, Imam. (2009) Model Persamaan Struktural, Konsep Dan Aplikasi Dengan Program AMOS 16.0. Badan Penerbit Universitas Diponegoro.

Hair, JF, Anderson RE Tatham, RL. (1998) Multivariate Analysis. 5 Edition. Prentice Hall International, Inc.

Javadi, Mohammad Hossein, Hossein Rezaei Dolatabadi, Mojtaba Nourbakhsh, Amir Porsaeedi, Ahmad Reza Asadollahi (2012) "An Analysis of Factors Affecting on Online Shopping Behavior of Consumers". Internasional Journal of Marketing Studies; 4 (5)

Lee, Ji-Hwan., Chi-Hoon Song. (2013) Effects of Trust And Perveived Risk On User Acceptance Of A New Technology Service. Social Behavior and Personality, 41 (4).

Li., Yan, Chuan-Hoo Tan, Heng Xu, Hock-Hai Teo. (2011) "Open Source Software Adoption: Motivations of Adopters and Amotivations of Non-adopters". The DATA BASE for Advances in Information Systems. 42 (2), May.

Lind., A. Douglas., William G. Marchal, Samuel A. Wathen. (2008) Teknik-teknik Statistika dalm Bisnis dan Ekonomi Menggunakan Kelompok Data Global. Edisi 13. Buku 2. Penerbit Salemba Empat.

Suhendra, E.Susy., Budi Hermana, dan Toto Sugiarto. (2009) Behavioral Analysis of Information Technology Acceptance in Indonesia Small Enterprices. Paper presented at EconAnadolu 2009: Anadolu International Conference in Economics. June 17-19, 2009, Eskişehir, Turkey. 
Widyartono dan Tyra: Pengaruh Kepercayaan dan Resiko erhadap Sikap dan Perilaku...

Wu, Wann-Yih., Ching-Ching Ke. (2015) An Online Shopping Behavior Model Integrating Personality Traits, Perceived Risk And Technology Acceptance. Social Behavior and Personality, 43(1).

Yusuf. Oik. (2014) Pengguna Internet Indonesia nomor enam dunia http://tekno.kompas.com/read/2014/11/24/07430087/ 